\title{
Mannose binding lectin genes (MBL2) polymorpshisms and the periodontal disease in diabetic patients
}

\section{Polimorfimos da lectina de ligação da manose (MBL2) e doença periodontal em pacientes diabéticos}

\begin{abstract}
Purpose: To assess the association between the polymorphism in exon-1 of the MBL2 gene and the periodontal disease in type 2 diabetic patients.

Methods: The sample comprised of 100 patients, who were submitted to a clinical periodontal examination that evaluated in six sites per tooth the probing depth (PD), bleeding on probing $(\mathrm{BOP})$, clinical attachment loss (CAL), plaque index (PI) and the number of teeth present. Periodontal disease was defined as at least four sites with loss of attachment of $\geq 5 \mathrm{~mm}$, with one or more of those sites having a pocket of $\geq 4 \mathrm{~mm}$. The collection of scaling cells from the oral mucosa was carried out and the detection of MBL2 polymorphism was made by real time PCR and melting temperature curve analysis.

Results: In a type 2 diabetic population, no significant statistical differences in MBL2 polymorphisms genotype or allele frequencies were observed among subjects with periodontal disease.

Conclusion: This study indicates that the polymorphisms in exon- 1 of the MBL2 gene are not related to periodontal disease in a type 2 diabetic population.
\end{abstract}

Key words: Polymorphism; periodontitis; Diabetes Mellitus

\section{Resumo}

Objetivo: Avaliar a associação entre o polimorfismo no exon-1 do gene MBL2 e a doença periodontal em pacientes diabéticos tipo 2.

Método: A amostra foi composta por 100 pacientes que foram submetidos a um exame clínico periodontal que avaliou seis sítios por dente a profundidade de sondagem (PS), sangramento à sondagem (SS), perda de inserção clínica (PIC), índice de placa (IP) e o número de dentes presente. A doença periodontal foi definida como pelo menos quatro sítios com perda de inserção de $\geq 5 \mathrm{~mm}$, com um ou mais destes sítios tendo uma bolsa de $\geq 4 \mathrm{~mm}$. Foram coletadas células de descamação da mucosa oral e a detecção do polimorfismo foi feita através da PCR em tempo real e análise da temperatura de melting.

Resultados: Em uma população de diabéticos tipo 2, não houve diferenças estatisticamente significantes nos genótipos do polimorfismo da MBL2 ou freqüência alélica observadas entre os indivíduos com doença periodontal.

Conclusão: Este estudo indicou que o polimorfimos no exon-1 do gene da MBL2 não foi relacionado à doença periodontal em uma população de diabéticos tipo 2.

Palavras-chave: Polimorfismo; periodontite; Diabetes mellitus

\author{
Natália Costa Araújo a \\ Darcyla Maria de Aguiar Bello a \\ Sergio Crovella ${ }^{b}$ \\ Paulo Roberto Eleutério de Souza c \\ Nikos Donos ${ }^{d}$ \\ Renata Cimões e
}

- Graduate Program, Federal University of Pernambuco, Recife, PE, Brazil

${ }^{b}$ Genetic Department, Federal University of Pernambuco, Recife, PE, Brazil

c Biology Department, Rural Federal University of Pernambuco, Recife, PE, Brazil

dPeriodontology Unit, Eastman Dental Hospital, University College London, London, United Kingdom

e Department of Prosthesis and Oral and Facial Surgery, Federal University of Pernambuco, Recife, PE, Brazil

\author{
Correspondence: \\ Renata Cimões \\ Pós-Graduação em Odontologia \\ Av. Prof. Moraes Rego, 1235, Cidade Universitária \\ Recife, PE - Brazi \\ 50670-901 \\ E-mail:renata.cimoes@globo.com
}

Conflict of Interest Statement: The authors state that there are no financial and personal conflicts of interest that could have inappropriately influenced their work.

Copyright: (C) 2011 Araújo et al.; licensee EDIPUCRS. This is an Open Access article distributed under the terms of the Creative Commons AttributionNoncommercial-No Derivative Works 3.0 Unported License. 


\section{Introduction}

The human collectin, mannose-binding lectin (MBL), is an important protein of the humoral innate immune system. With multiple carbohydrate-recognition domains, it is able to bind to sugar groups displayed on the surfaces of a wide range of microorganisms. It is recognized to have a role in processes as diverse as complement activation, promotion of complement-independent opsonophagocytosis, modulation of inflammation, recognition of altered self-structures and apoptotic cell clearance (1).

The basic structural unit of MBL is a homotrimer of MBL peptides (sub-units) that self-associate into a collagen-like triple helix. Each peptide possesses a C-terminal calciumdependent lectin domain (CRD), which recognizes repetitive oligosaccharide moieties present on a wide array of pathogens; a short $\alpha$-helical, hydrophobic neck region; a collagenous region and a cysteine-rich N-terminal region. Functional MBL circulates as higher order multimers (tetramers, pentamers and hexamers) of the structural (homotrimeric) unit. The higher order structure allows high-affinity interaction between MBL lectin domains and microbial oligosaccharides, resulting in conformational change of the MBL multimer and activation of associated molecules, the mannose-associated serine proteases (MASP) (2).

There are two human MBL genes, but MBL-1 is a pseudogene and only MBL-2 encodes a protein product. The functional MBL-2 gene is located on chromosome 10 (q11.2-q21) and comprises four exons. Exon 1 encodes the signal peptide, a cysteine-rich region and part of the glycinerich collagenous region. Exon 2 encodes the remainder of the collagenous region and exon 3 encodes a $\alpha$-helical coiledcoil structure, which is known as the "neck" region. Exon 4 encodes the CRD, which assumes a globular configuration. The promoter region of the MBL gene contains a number of regulatory elements that affect transcription of the protein(1-3).

In 1991, the complete nucleotide sequence of all four exons of the human MBL-2 gene was determined and a point mutation was observed in codon 54, substituting aspartic acid for glycine (4); in 1992, a second exon 1 mutation was identified in codon 57, resulting from the exchange of glycine by glutamic acid (5); and in 1994, a mutation was reported in codon 52, substituting arginine by cysteine (6). These point mutations are usually referred to as variants B, $\mathrm{C}$ and $\mathrm{D}$ respectively and are designated as allele 0 , whereas the allele A indicating the wild type (3).

A common opsonic defect was found to be associated with low levels of the mannose-binding protein (7). Subsequently, low levels of this protein were associated with recurrent infections in childhood (8). A variety of medical conditions have been related with MBL deficiency, such as acquired immunodeficiency syndrome (9), heart disease (3) and diabetes mellitus (10).

Diabetes mellitus is a metabolic disorder characterized by increased levels of glucose in the bloodstream because of defective secretion or activity of the hormone insulin (11). Type 1 diabetes results from cellular mediated autoimmune destruction of pancreatic b-cells, usually leading to total loss of insulin secretion (12). Type 2 diabetes results from insulin resistance and does not seem to have an auto-immune causation, because no destruction of cells of pancreatic islets is seen microscopically (13).

Diabetes mellitus is recognized as one of the main public health problems in Latin America affecting nearly 19 million people in the region. In Brazil it is estimated that the prevalence of this disease is $7.6 \%$ of the population older than 40 years (14). Peripheral vascular failure in diabetic patients impairs healing and produces physiological changes that decrease the capacity of the immune system, thereby increasing susceptibility to infections (15).

Periodontal disease is the most common dental manifestation in the oral cavity of diabetic patients (16) and has been reported to be the sixth classic complication of the diabetic patient (17). It is generally accepted that the presence of bacteria is a necessary but not sufficient condition for the development of periodontitis (18).

The relationship between the periodontopathogenic potential of the plaque and the immune response of the host determines the development of periodontal disease (19). As the immune system plays an important role in the pathogenesis of the periodontal disease (20), it is conceivable that changes in serum levels of MBL due to genetic polymorphisms may be part of the susceptibility to periodontitis.

Interestingly, the periodontal pathogens Aggregatibacter actinomycetemcomitans and Porphyromonas gingivalis also appear to have mannan-rich polysaccharides on the cell surfaces, which can be a potential target for MBL binding (21). For this reason the MBL can play an important role in host defense against periodontal pathogens.

This study investigated the association of periodontal disease with genetic polymorphism of the exon-1 (codons $-52,-54,-57)$ of MBL2 gene using the technique of real-time PCR in a sample of Brazilian patients with type 2 diabetes mellitus.

\section{Materials and Methods}

The research project received approval from the Ethics in Research Committee of the Federal University of Pernambuco (protocol number 285/07). This study was carried out at two endocrinology services of the public healthcare system in Recife, Brazil (Hospital das Clínicas and Centro Médico Senador Ermírio de Moraes). A total of 100 patients with prior diagnosis of type 2 diabetes were evaluated between April $1^{\text {st }}$ and July $30^{\text {th }}, 2008$. The sample was randomly obtained in accordance with the demand at the clinics involved.

All patients who presented for consultation during this period were approached and selected using the following inclusion and exclusion criteria.

Inclusion criteria:

1 - Diagnosis of type 2 diabetes;

2 - Having at least eight natural teeth;

3 - Agreeing to participate in the study. 
Exclusion criteria:

1 - Using antibiotics for at least 6 months;

2 - Major medical complications (e.g. heart disease);

3 - Periodontal treatment in the previous 6 months;

4 - Being pregnant or breastfeeding.

After free and informed written consent had been obtained, a clinical examination was performed in a dental chair by two previously calibrated researchers using a millimeter North Carolina-type (Trinity ${ }^{\circledR}$ - São Paulo, SP, Brazil) periodontal probe. Six sites per tooth were evaluated (distobuccal, midbuccal, mesiobuccal, distolingual, midlingual and mesiolingual), except for third molars. PD, BOP, CAL, PI and number of teeth present were recorded.

Periodontal disease was defined as four or more sites with a loss of attachment of $5 \mathrm{~mm}$ or more with one or more of those sites having a pocket of $4 \mathrm{~mm}$ or more (22). The loss of attachment corresponds to the distance from the most apical portion of the periodontal pocket to the cementoenamel junction. Thus the sample was divided into a control group (diabetic patients without periodontitis) and a study group (diabetic patients with periodontitis).

\section{DNA isolation}

After clinical examination, the collection of the scaling cells from the oral mucosa was carried out with appropriate cytobrush-type brushes (Kolplast ${ }^{\circledR}$ - São Paulo, SP, Brazil), which were subsequently stored in $1 \mathrm{ml}$ of saline solution of $0.9 \%$ chloride sodium (Laboratory Tayuyna Ltda - Nova Odessa, SP, Brazil). The collected material was stored at $-20^{\circ} \mathrm{C}$ for extraction of the DNA.

The kit for extraction and purification of DNA, Geneclean $^{\circledR}$, $\left(\right.$ GENECLEAN ${ }^{\circledR}$ Kit, BIO 101, La Jolla, CA, USA) was used to extract the genetic material according to manufacturer's protocol.

\section{MBL2 genotyping}

The detection of polymorphism in the MBL2 gene was conducted by the technique of real time PCR (RT-PCR) using the melting temperature curve analysis (23).

MBL2 SNP genotyping was performed using the following primers designed with the Primer Express 1.5 software (Applied Biosystems, Foster City, CA, USA): forward primer 5'-AGGCATCAACGGCTT CCCA-3' and reverse primer 5'-CAGAA CAGCCCAACACGTACCT-3'. The expected amplicon length is $90 \mathrm{bp}$ and its theoretical melting temperature is $84^{\circ} \mathrm{C}$. Amplification reactions were performed in a final volume of $25 \mu \mathrm{L}$ with $1 \mathrm{X}$ SYBR Green I Amplification Master Mix (Euroclone, Milan, Italy), 150 picomoles of the forward primer, 50 picomoles of the reverse primer and $10 \mathrm{ng}$ of genomic DNA. The cycling conditions were as follows: $95^{\circ} \mathrm{C}$ for $10 \mathrm{~min}$ followed by $95^{\circ} \mathrm{C}$ for $30 \mathrm{~s}$ and $60^{\circ} \mathrm{C}$ for $1 \mathrm{~min}$, repeated 40 times in the Rotor Gene-3000 apparatus (Corbett Research Mortlake, Sydney, Australia). At the end of the PCR, the dissociation protocol included a slow heating from $60^{\circ}$ to $95^{\circ} \mathrm{C}$ in $0.2^{\circ} \mathrm{C}$ steps, with an 8 -s interval between steps. Melting curve profiles were obtained using the dissociation software of the Rotor Gene-3000 apparatus (9).
The melting temperature assay allowed us to easily distinguish the melting profiles of the three MBL2 genotypes, which were AA, A0, and 00, respectively. The melting temperatures of the three MBL2 genotypes were as follows: $\mathrm{A} / \mathrm{A}$ (one peak of $83.1 \pm 0.1^{\circ} \mathrm{C}$ ), $\mathrm{A} / 0$ (two peaks of $82.6 \pm 0.3$ and $80.7 \pm 0.1^{\circ} \mathrm{C}$ ), and $0 / 0$ (one peak of $81.7 \pm 0.1^{\circ} \mathrm{C}$ ) (9).

The genotyping was performed by overlapping the patients' curves with the curves of three control samples: one wild, one mutant and one for a heterozygote. Whenever there was an overlap between the curve of the patient with a standard curve, it was possible to infer the genotype in question.

The MBL2 genotype frequencies were in agreement with the Hardy-Weinberg equilibrium. Allele frequencies were calculated by direct gene counting and the differences analyzed by Fisher's exact test.

The confidence interval considered was $95 \%$, so p-values less than 0.05 were accepted. The results that did not attain this value were considered to be without significance. All data analyses were performed using the statistical package SPSS version 13.0 (SPSS Inc., Chicago, IL, USA).

\section{Results}

The mean age of the patients during the data collection was 54.1 years $(\mathrm{SD}=9,54), 37 / 100(37.0 \%)$ being male and $63 / 100(63.0 \%)$ female. Table 1 presents the measurements of descriptive analysis that characterize the sample studied.

Table 1. Descriptive analysis of the number of teeth present, percentage of bleeding and plaque in a type 2 diabetic Brazilian sample $(n=100)$.

\begin{tabular}{lccc}
\hline & $\begin{array}{c}\text { Number of } \\
\text { teeth present }\end{array}$ & $\begin{array}{c}\text { Percentage of } \\
\text { bleeding on probing }\end{array}$ & $\begin{array}{c}\text { Percentage of } \\
\text { dental plaque }\end{array}$ \\
\hline Mean & 16.42 & 34.44 & 63.83 \\
Median & 16.00 & 25.00 & 67.87 \\
SD & 6.563 & 24.34 & 29.33 \\
Minimum & 8 & 0.00 & 6.40 \\
Maximum & 32 & 100.00 & 100.00 \\
\hline
\end{tabular}

The prevalence of periodontal disease in the sample studied is reported in Table 2. Sixty and one per cent of the patients had periodontitis and 39\% were healthy individuals. Regarding the distribution of genotypes, the sample presented $46.0 \%$ with the AA genotype, $54.0 \%$ the A0 and $0.0 \%$ the 00 genotype.

The association between MBL2 polymorphism and periodontal disease is reported in Table 3: MBL2 polymorphisms genotype frequencies were in agreement with the Hardy-Weinberg equilibrium in both patients and controls. The frequencies of MBL2 polymorphisms reveal that $45.9 \%$ of the periodontitis patients were carrying the AA genotype and $54.1 \%$ the A0 genotype, while the healthy 
controls were carrying $46.2 \%$ and $53.8 \%$, respectively. There were no significant differences between periodontitis patients and controls in the distribution of the genotypes

MBL2 polymorphisms allele frequency is also shown in Table 3. In the periodontitis group, $72.9 \%$ were carrying the A allele and $27.1 \%$ the 0 allele versus $73.0 \%$ and $27.0 \%$, respectively, of the controls. The results indicated that there were no statistically significant differences in the frequency of the alleles of the MBL2 gene between the healthy and periodontitis individuals.
Table 2. Frequency and percentage of the periodontitis and the MBL genotypes in a type 2 diabetic Brazilian sample $(n=100)$.

\begin{tabular}{lcc}
\hline & Frequency & Percentage \\
\hline Distribution of periodotitis & & \\
Periodontitis patients & 61 & 61.0 \\
Healthy patients & 39 & 39.0 \\
Distribution of MBL genotypes & & \\
AA & 46 & 46.0 \\
A0 & 54 & 54.0 \\
O0 & 0 & 0.0 \\
Total & 100 & 100.0 \\
\hline
\end{tabular}

Table 3. Polymorphism frequencies in exon- 1 of the MBL2 gene in type 2 diabetic patients with periodontitis and healthy controls.

\begin{tabular}{|c|c|c|c|c|c|}
\hline & \multicolumn{4}{|c|}{ Periodontal Disease } & \multirow{3}{*}{$P^{*}$ value } \\
\hline & \multicolumn{2}{|c|}{ Case } & \multicolumn{2}{|c|}{ Healthy } & \\
\hline & $\mathrm{n}$ & $\%$ & $\mathrm{n}$ & $\%$ & \\
\hline \multicolumn{6}{|c|}{ MBL2 genotype frequencies } \\
\hline $\mathrm{AA}$ & 28 & $45.9 \%$ & 18 & $46.2 \%$ & \multirow{3}{*}{0.57} \\
\hline $\mathrm{AO}$ & 33 & $54.1 \%$ & 21 & $53.8 \%$ & \\
\hline Total & 61 & $100 \%$ & 39 & $100 \%$ & \\
\hline \multicolumn{6}{|c|}{ MBL2 allele frequencies } \\
\hline A & 89 & $72.9 \%$ & 57 & $73.0 \%$ & \multirow{2}{*}{0.51} \\
\hline 0 & 33 & $27.1 \%$ & 21 & $27.0 \%$ & \\
\hline
\end{tabular}

${ }^{*}$ Fisher's exact test

\section{Discussion}

It is well established that patients with diabetes exhibit a slight increase in the severity of periodontal disease when compared to non-diabetic (18). The present study showed a high frequency of periodontal disease in the diabetic population, $61 \%$ of the sample having periodontal disease. These results are in agreement with many studies that investigated the relationship between type 2 diabetes and periodontitis and observed the widespread existence of periodontal disease in this population $(19,22)$.

Several biological mechanisms were proposed for a higher predisposition to periodontitis of diabetic subjects and include microangiopathy, neutrophil and leukocyte dysfunction, genetic predisposition, changes in collagen metabolism and in subgingival microbiota (17).

It is known that genetic heterogeneity can be a problem when we perform genetic screenings in Brazilian populations which characterized by an admixture of genotypes. It is not easy to determine the ethnic origin of Brazilian population, especially those of Northeastern Brazil who are known to derive from an admixture of African, Caucasian and Native American populations (estimated respectively, at 44\%, 34\%, and $22 \%$ ) (24).

Although the genetic polymorphism of the MBL promotes the development of various diseases, it is still observed at high frequencies in populations. It has been suggested that the persistence of MBL gene polymorphisms at high frequencies may offer a potential advantage to the host. The low levels of functional MBL could reduce possible deleterious consequences owing to complement activation and subsequent release of inflammatory mediators that may lead to tissue damage (25).

In general, one-third of the white population is considered MBL deficient. Genetic studies are needed to link genetic polymorphism and susceptibility to the development of various diseases (26).

Homozygotes individuals for the mutant allele $(0 / 0)$ produce MBL in undetectable quantities by enzymelinked immunosorbent assay (ELISA), while heterozygotes for the mutation (A/0) produce significantly reduced concentrations when compared with homozygotes individuals for the wild type allele (A/A) (5). In a recent review of the MBL2 gene, frequencies of the low-producing (A0) and deficient genotypes (00) of around $40 \%$ were reported for two Caucasian populations (Danish and British) (25). For one Brazilian population, the frequencies of these genotypes were $38.9 \%$ (9). In this study, in a type 2 diabetic population of northeast Brazil, the findings are similar to those of the previously reported frequencies, and the prevalence of genotypes encoding low MBL plasma levels (A0) was $54 \%$.

Some studies related the association between MBL2 gene polymorphisms with diabetes mellitus. Patients with type 1 diabetes possessing the 0 allele have a higher risk for developing type 1 diabetes during childhood and adolescence 
(10). In patients with type 2 diabetes, measurements of MBL can provide prognostic information on mortality and the development of vascular complications (27).

In the current literature, few studies analyzed the correlation between the polymorphism of the MBL2 gene and the periodontal disease. Louropoulou et al. (28) investigated the correlation of polymorphisms in the MBL2 gene in relation to periodontitis in Caucasian population and observed that the prevalence of genotypes encoding for low and very low MBL plasma levels was higher for periodontitis patients than for healthy controls $(44 \%$ and $35 \%$, respectively). In the present study, $54 \%$ of the patients displayed genotypes encoding low MBL plasma levels (A0), of whom $54.09 \%$ had periodontal disease and $53.84 \%$ were healthy controls. Neither the present study nor that of Louropoulou et al. (28) and Araújo et al. (29) was able to detect any statistically significant differences in the genotype frequencies between periodontitis patients and healthy controls. The results of this study may have had interference of some limitations such as: sample size and no characterization of group ethnic.

In a previous study, Maffei et al. (26) analyzed MBL plasma levels in relation to periodontitis and demonstrated that MBL levels were not high in periodontitis and that MBL deficiency was not related to susceptibility to periodontitis. Despite those results are in agreement with the data recorded by this study and do not offer a basis for implicating MBL deficiency in the pathogenesis of periodontitis, further studies with different ethnic groups will be needed before more substantiated conclusions can be drawn.

\section{Conclusion}

This study indicates that the polymorphisms in exon-1 of the MBL2 gene are not related to periodontal disease in a type 2 diabetic population.

\section{References} . Dommett RM, Klein N, Turner MW. Mannose-binding lectin in innate immunity: past, present and future. Tissue Antigens 2006;68:193-209.

2. Worthley DL, Bardy PG, Mullighan CG. Mannose-binding lectin: biology and clinical implications. Intern Med J 2005;35:548-55.

3. Turner MW. The role of mannose-binding lectin in health and disease. Mol Immunol 2003;40:423-29.

4. Sumiya M, Super M, Tabona P, Levinsky RJ, Arai T, Turner MW et al. Molecular basis of opsonic defect in immunodeficient children. Lancet 1991;337:1569-70.

5. Lipscombe RJ, Sumiya M, Hill AVS, Lau YL, Levinsky RJ, Summerfield JA et al. High frequencies in African and non-African populations of independent mutations in the mannose binding protein gene. Hum Mol Genet 1992;1:709-15.

6. Madsen HO, Garred P, Kurtzhals JA, Lamm LU, Ryder LP, Thiel S et al. A new frequent allele is the missing link in the structural polymorphism of the human mannan-binding protein. Immunogenetics 1994;40:37-44.

7. Super M, Thiel S, Lu J, Levinsky RJ, Turner MW. Association of low levels of mannan-binding protein with a common defect of opsonization. Lancet 1989;2:1236-9.

8. Cedzynski M, Szemraj J, Swierzko AS, Bak-Romaniszyn L, Banasik M, Zeman K et al. Mannan-binding lectin insufficiency in children with recurrent infections of the respiratory system. Clin Exp Immunol 2004;136:304-11.

9. Arraes LC, Souza PR, Bruneska D, Castelo Filho A, Cavada BS, de Lima Filho JL et al. A cost-effective melting temperature assay for the detection of single-nucleotide polymorphism in the MBL2 gene of HIV-1 -infected children. Braz J Med Biol Res 2006;39:719-23.

10. Araújo J, Brandão LA, Guimarães RL, Santos S, Falcão EA, Milanese M et al. Mannose binding lectin gene polymorphisms are associated with type 1 diabetes in Brazilian children and adolescents. Hum Immunol 2007;68:739-43.

11. Kiran M, Arpak N, Ünsal E, Erdogan MF. The effect of improved periodontal health on metabolic control in type 2 diabetes mellitus. J Clin Periodontol 2005;32:266-72.

12. Mealey BL, Oates TW. Diabetes mellitus and periodontal disease. J Periodontol 2006;77:1289-303.

13. Donahue RP, Wu T. Insulin resistance and periodontal disease: an epidemiologic overview of research needs and future directions. Ann Periodontol $2001 ; 6: 119-24$.

14. King H, Aubert RE, Herman WH. Global burden of diabetes, 1995-2025: prevalence, numeral estimates, and projections. Diabetes Care 1998;21:1414-31.

15. lacopino AM. Periodontitis and diabetes interrelationships: the role of inflammation. Ann Periodontol $2001 ; 6: 125-37$.

16. Sousa RR, Castro RD, Monteiro CH, Silva SC, Nunes AB. Buccal attendance of the patient with diabetes mellitus: a revision of literature (in Portuguese). Pesq Bras Odontoped Clin Integr 2003;3:71-7.

17. Löe H. Periodontal disease. The sixth complication of diabetes mellitus. Diabetes Care 1993; 16:329-34. 
18. Socransky SS, Haffajee AD, Cugini MA, Smith C, Kent Jr RL. Microbial complexes in subgingival plaque. J Clin Periodontol 1998; 25:134-44.

19. Newman MG, Takei HH, Carranza FA. Clinical Periodontology (in Portuguese) 9. ed. Rio de Janeiro: Guanabara Koogan; 2004:1 18-36.

20. Loos BG, John RP, Laine ML. Identification of genetic risk factors for periodontitis and possible mechanisms of action. J Clin Periodontol 2005;32(Suppl6):159-79.

21. Farquharson SI, Germaine GR, Gray GR. Isolation and characterization of the cell-surface polysaccharides of Porphyromonas gingivallis ATCC 53978. Oral Microbiol Immunol 2000; 15:151-157.

22. Nelson RG, Shlossman M, Budding LM, Pettitt DJ, Saad MF, Genco RJ et al. Periodontal disease and NIDDM in Pima Indians. Diabetes Care 1990;13:836-40.

23. Boniotto ML, Braida I, Pirulli D, Arraes L, Amoroso A, Crovella S. MBL2 polymorphisms are involved in HIV-1 infection in Brazilian perinatally infected children. AIDS 2003; 17: 779-80.

24. Alves-Silva J, da Silva Santos M, Guimarães PE, Ferreira AC, Bandelt HJ, Pena SD et al. The ancestry of Brazilian mtDNA lineages. Am J Hum Genet 2000;67:444-61.

25. Garred P, Larsen F, Seyfarth J, Fujita R, Madsen HO. Mannose-binding lectin and its genetic variants. Genes Immun 2006;7:85-94.

26. Maffei G, Brouwer N, Dolman KM, van der Velden U, Ross D, Loss BG. Plasma levels of mannan-binding lectin in relation to periodontitis and smoking. J Periodontol 2005;76:1881-9.

27. Hansen TK, Gall MA, Tarnow L, Thiel S, Stehouwer CD, Schalkwij CG et al. Mannosebinding lectin and mortality in type 2 diabetes. Arch Intern Med 2006;166:2007-13.

28. Louropoulou A, Schoenmaker T, Catsburg A, Savelkoul PHM, Loos BG. Mannose-binding lectin gene polymorphisms in relation to periodontitis. J Clin Periodontol 2008;35: 923-30.

29. Araújo NC, Bello DMA, Souza PRE, Cimões R. Association of polymorphism MBL2 gene in type 2 diabetic patients with periodontitis: a preliminary study. Acta Stomatol Croa $2009 ; 43: 290-300$ 